\title{
A közelmúlt magyar irodalmi kroatisztikája
}

\author{
KÁlecz-Simon Orsolya \\ ELTE BTK, Szláv Filológiai Intézet, Múzeum krt. 4/D, \\ HU-Budapest,kaleczo@gmail.com
}

\begin{abstract}
Pričujoča študija podaja pregled razvoja madžarske literarne kroatistike v času po spremembi političnega sistema. Po predstavitvi novih izzivov, ki so se pojavili v 90-ih letih 20 . stoletja, bodo skicirani portreti najpomembnejših osebnosti madžarske kroatistike, in sicer s kritično predstavitvijo njihovih glavnih del, ciljev ter metodoloških sredstev.
\end{abstract}

SCN V/2 [2012], 70-81

The following paper presents the most important tendencies of the studies of Croatian Literature in Hungary. After presenting the new challenges appeared in the 1990s, we draft the portraits of the most important Hungarian professionals of Croatian (Literary) Studies, presenting their most important works, goals and their methodology.

Ključne besede: Madžarska, kroatistika, književnost, Stipan Blažetin, István Fried, László Heka, István Lőkös, Stjepan Lukač, Zoltán A. Medve, Zoltán Virág

Key words: Hungary, Croatian Studies, literature, Stipan Blažetin, István Fried, László Heka, István Lőkös, Stjepan Lukač, Zoltán A. Medve, Zoltán Virág

A délszláv állam széthullása, a kommunista diktatúra megszünése és az önálló horvát állam megszületése több okból is átalakította a kroatisztikát. A horvátországi kroatisztika még markánsabban elhatárolódott a többi délszláv irodalommal foglalkozó diszciplínától, a tudomány meghatározó szakembereinek köre kicserélödött, a horvát irodalmi és az irodalomtörténeti kánonban pedig jól látható elmozdulások következtek be. Ezeknek az átrendeződéseknek a magyar tudományos életben is meghatározó jelentősége volt; a délszláv nyelvek és irodalmak kényszerü-erőltetett együtt-tárgyalása helyett különkülön diszciplínák jöttek létre, amelyek az egyes délszláv népek nyelvére és irodalmára koncentráltak. Tulajdonképpen a szó szoros értelmében vett magyar kroatisztika megszületéséről is csak innentől beszélhetünk. A Magyarországot 
érintő politikai változások hatására ugyanakkor a magyarországi irodalommal kapcsolatos diskurzusokban is olyan változások mentek végbe, olyan új témák és kérdések merültek föl, amelyek jelentős kihívások elé állították az újonnan született magyar kroatisztikát.

A diszciplína legfontosabb kihívása egyértelmủen az irodalomtudomány minden területére kiterjedő paradigmaváltással, az ,irodalomelméleti fordulattal" való szembenézés volt. A Nyugaton már jó ideje létező irodalomelméleti irányzatok eredményei, megközelítései a rendszerváltás idején - robbanásszerü hirtelenséggel - Magyarországra is betörtek, és rövid idő alatt teljesen átformálták az irodalomról való gondolkodást. A magyar irodalomtudósok csakhamar felismerték a 20. század második felében színre lépő irodalomelméleti iskolák felfedezéseinek jelentőségét, amelyeket saját elemzéseikbe, kutatásaikba is beépítettek, nem egyszer a különféle megközelítési lehetőségek ötvözésével kísérletezve. Ez a paradigmaváltás egyúttal az összehasonlító irodalomtudomány válságának felismerését is magával hozta. Fried István az Utak a komparatisztikában címü tanulmánykötet bevezetőjében rámutat, hogy a „francia iskola” nyomdokait követő, egyre inkább kiüresedő összehasonlító irodalomtudományra a legnagyobb csapást az orosz formalisták széles körü nyugati recepciója, illetve a recepcióesztétikai megközelítés mérte (Fried 1997: 1). A Fried által szerkesztett kötet, amelyet éppen a komparatisztika újragondolásának, módszertani felfrissítésének igénye hívott életre, többek között az intertextuális kutatások, a mítoszkritika, a szövegszociológia és a kulturális kritika alkalmazását, valamint az areális szemlélet előtérbe helyezését javasolta (ld. Fried 1997). Miután a magyarországi irodalmi kroatisztika komparatív alapokon áll, fö feladatának pedig a magyar és a horvát kultúra közötti - kétirányú - közvetítést tekinti, ezekkel a kérdésekkel a magyarországi kroatistáknak is szembe kellett néznie. A kihívásra Lukács István reagált a leggyorsabban, aki szellemes, változatos elméleti eszközökre építő „kísérleti komparatisztikai megközelítésekkel" kereste a diszciplína megújításának lehetőségeit; a később színre lépő Medve A. Zoltán és Virág Zoltán számára pedig már magától értetődő dolognak számított a változatos irodalomelméleti eszköztár alkalmazása. Későbbi tanulmányaiban Fried István is változatos, egyedi megközelítésekkel, problémafelvetésekkel járult hozzá a magyar kroatisztika megújításához.

A korszakváltás eredményeként számos új kutatási téma is diszciplínánk látóterébe került. Komparatív alapállásából adódóan a magyar kroatisztika elsődlegesen a magyar és a horvát kultúra genetikai kapcsolatait vizsgálta; ezért a magyar kroatisták föként a régi horvát irodalomra, továbbá Miroslav Krleža munkásságára koncentráltak. Jóllehet később - elsősorban Lőkös István és Lukács István erőfeszítéseinek hatására - az illírizmus, a realizmus, a premodern, a modernség és az avantgárd más képviselői is a fókuszba kerültek, a Krleža után színre lépő alkotókról Magyarországon csupán elvétve születtek tanulmányok. ${ }^{1}$ Bár a II. világháború és a rendszerváltás közötti időszakban,

${ }^{1}$ Talán a horvát farmernadrágos prózát leszámítva, amelynek magyar hatásáról, párhuzamairól Milosevits Péter több fontos tanulmányt publikált. 
a magyarság és a horvátság hasonló berendezkedése, politikai helyzete okán, az irodalmakban is párhuzamos jelenségek mutathatók ki, addig a balkáni háborúk, a megélt traumákkal való szembenézés kényszere radikálisan más kihívások elé állította a horvát és a magyar irodalmat. Míg a magyar irodalmat a világ leírhatóságába vetett hit megingása jellemezte (Medve 2009: 99-100), a horvát irodalom egyértelműen a dokumentarizmus, a mimetizmus felé orientálódott. A kétféle megközelítés, problémakör távoliságát jól példázza az az értetlenség, ahogyan Miljenko Jergović, a horvát irodalom meghatározó egyénisége, Esterházy Harmonia Caelestiséről szól Idiotizacija naše kulture címü publicisztikájában. Ezzel magyarázhatjuk azt a tényt is, hogy a közelmúltban átültetett horvát szövegek rendre visszhangtalanok maradtak. Az 1990-es évek elején tehát a kultúrák közötti közvetítésre hagyományosan nagy hangsúlyt fektető magyarországi kroatisztikának két fontos kérdést is meg kellett válaszolnia: 1) Mi a teendő a horvát posztmodernnel? 2) Van-e mód a 90-es évek horvát és magyar irodalma közötti közvetítésre, és ha igen, akkor mi az? E kérdésekre Medve A. Zoltán adott csattanós választ Kontextusok és annotációk címü tanulmánykötetével.

Végül, az elmúlt 20 év a magyar kroatisztika egyik fontos kiágazása, a kisebbségi irodalmakról szóló diskurzusok tekintetésben is fontos változásokat hozott. Szemben a korábbi évek gyakorlatával, amely a kisebbségi irodalmakat a margóra taszította, az új elméleti perspektíváknak köszönhetően a szakértők egyre inkább felismerték a periférián születő irodalmi alkotások fontosságát és lehetőségeit. A periférián egyrészt különféle kultúrák találkoznak, másrészt kevésbé érvényesek a centrumok konvenciói, regulatív elvei, így lehetővé válik a kultúrák kölcsönösen termékenyítő párbeszéde-keveredése; a perifériáról kiinduló változások pedig sokszor egészen a centrumig hatnak. A magyarországi szépirodalmi szcéna hagyományosan odafigyel a kisebbségi színterek eseményeire, a rendszerváltás pedig jelentősen megkönnyítette a határon túli régiók és az anyaország közötti kommunikációt, ami lehetővé tette azt, hogy a kisebbségi irodalmakról zajló diskurzusok a centrum közegeibe is eljuthassanak. Ennek eklatáns példája Virág Zoltán az Új Symposion címú vajdasági folyóirat szerzőit bemutató tanulmánykötete, amely a symposionisták kontextusának, szellemi horizontjának megrajzolásához a kroatisztikát, a szerbisztikát és a szlovenisztikát hívja segítségül. A horvát irodalmi színteret ez a nyitottság egyelőre nem jellemzi, de a kedvezőbbé váló politikai viszonyok a magyarországi horvát kultúra szakszerü önreflexiójának feltételeit is megteremtették; ennek egyik ígéretes első lépése Blazsetin István irodalomtörténete, valamint Virág Zoltán - a kívülálló pozíciójából írott - a magyarországi horvát irodalomról szóló tanulmánya.

A jelen áttekintés célja a magyar irodalmi kroatisztika meghatározó egyéniségei, például Blazsetin István, Fried István, Lőkös István, Lukács István, Medve A. Zoltán és Virág Zoltán, illetve a horvát kultúráról szóló kézikönyvvel jelentkező Heka László a rendszerváltás óta eltelt alig több mint két évtizedben folytatott munkásságának áttekintése. A szakmai portrék felvázolása során elsősorban azokat a tanulmányköteteket, monográfiákat és összefoglalásokat vesz- 
szük tekintetbe, amelyeket a szerzők magyar nyelven, az irodalmi kroatisztika tárgykörében publikáltak.

\section{$1 \mathrm{Az}$ alapok lefektetése}

A közelmúlt legtermékenyebb kroatistája, Lőkös István (1933-) éppen az 1990-es években publikálta legfontosabb tanulmányait a Magyar és délszláv irodalmi tanulmányok [1989], a Déli szláv-magyar szellemi kapcsolatok [1997], a Zrínyi eposzának horvát epikai elözményei [1997] és A Kaptoltól a Ludovikáig [1997] címü kötetekben. Ekkor született ambiciózus, a maga nemében úttörönek számító munkája, A horvát irodalom története [1996] is. Bár a 2000-es években is számos könyve jelent meg (Nemzettudat, nyelv és irodalom [2002], Nemzettudat és regény [2004], Horvát-magyar és szerb-magyar irodalmi interferenciák [2007]), ezek tudományos szempontból kevés újdonságot hoznak, mivel nagyrészt olyan eredményeket mutatnak be, amelyeket szerzőjük korábban már közzétett.

Lőkös tanulmányainak elsődleges célja a horvát és a magyar irodalom közötti genetikai kapcsolatok feltárása. Bár a szövegek szinte az egész horvát irodalomtörténetet lefedik, a kezdetektől egészen a 20. század közepéig, a tudós érdeklődésének fókuszában a horvát reneszánsz és barokk, a 19. századi horvát regény, valamint Miroslav Krleža munkássága áll.

Módszertani szempontból a cikkek kevés újdonságot hoznak, Lőkös elsősorban a hagyományos filológia és a pozitivizmus eszköztárára támaszkodik. A legsikerültebb, legtöbbet idézett tanulmányai azok, amelyek egy-egy jeles horvát alkotó magyar irodalmi és kulturális kapcsolatrendszerét térképezik fel, ide tartoznak például a Krleža-tanulmányok, amelyekben a tudós elsőként igazolta, hogy a magyar inspirációk a világirodalmi jelentőségű horvát író teljes életművét át- meg átszövik.

A szövegközi kapcsolatok feltérképezése során Lőkös megmarad a konkrét szövegrészek ismétlődésének, a parafrázisok és a motívumátvételek detektálásánál. Jóllehet így is meggyőző eredményekre képes - talán legfontosabb munkájában, a Zrínyi eposzának horvát epikai elözményeiben például hitelt érdemlően igazolja a horvát törökellenes epikának a reneszánsztól a barokkig ívelő folyamatosságát, a műfaj magyar kiágazásait is meggyőzően bemutatva -, feltủnő, hogy a párhuzamok mélyrehatóbb elemzésére ritkán vállalkozik.

A szövegek strukturális - a prozódia, a narratív sajátosságok, a kompozíció, a képi világ stb. terén jelentkező - párhuzamaira Lőkös nem, vagy csupán általános megállapítások erejéig tér ki, részletekbe nemigen bocsátkozik. Ez a módszertani sajátosság egyszersmind korlát is; míg a régi horvát irodalomról szólva Lőkös értékes felismerésekkel gyarapította a magyarországi kroatisztikát, addig a realista regényekről szóló tanulmányokban már tetten érhető, hogy a módszertani alapfeltevések megválasztása miatt a regények számos vonása a látókörén kívül reked. Ez a hiányosság a Nemzettudat és regény című könyvben ütközik ki a leginkább, amely a narratológiai szempontok teljes mellőzésével kísérel 
meg képet adni a 19. horvát regény történetéröl. A 20. századi horvát irodalom alkotásairól pedig, amelyeknél először a szövegek belső összefüggésrendszere kerül a fókuszba, majd az irodalomelméleti paradigmaváltások éreztetik hatásukat, igen kevés releváns mondanivalója akad.

Lőkös István legambiciózusabb vállalása mégis $A$ horvát irodalom története című összegzés közreadása volt, amelyben a horvát irodalom történetét kifejezetten a magyar közönség számára, a magyar-horvát kapcsolatok történetének kidomborítása mellett kívánta bemutatni. A tájékozódás megkönnyítése érdekében a bemutatott korszakok történelmi hátterét, valamint az alkotók portréját is felvázolja. Az életrajzok ismertetése azonban nem egyszer az életmü bemutatásának rovására megy, az utóbbi pedig megragad az általánosságok - a jellemző témák körvonalazása és az alkotások hangulatának jellemzése - szintjén, míg az alkotások eszmei hátteréről, inspirációiról, strukturális jellemzőiről viszont keveset tudunk meg. A módszertani korlátok ennél a münél is éreztetik hatásukat: a protorealizmusról és realizmusról szóló fejezetek olvasásakor az olvasó hiányérzete egyre erősödik, amelyet a mủvek szüzséjének bőkezủen, de jobbára fölöslegesen közölt összefoglalása sem képes eloszlatni; az 1945 utáni horvát irodalmat bemutató fejezet pedig az újonnan színre lépő szerzők munkásságát csupán címszavakban ismerteti, ám az új irodalmi tendenciák kibontására nem kerül sor.

A magyarországi kroatisták közül Lukács István (1958-) volt az első, aki felismerte, hogy az új elméleti irányzatok magyarországi megjelenése az irodalmi kroatisztika módszertani alapjainak újragondolását is szükségessé teszi. A kroatisztika mellett szlovenisztikával is foglalkozó, szerteágazó tudományos és módszertani érdeklődésü Lukács a kérdést szellemes tanulmányok egész sorával válaszolta meg, amelyeket később - Térközök [2004] címmel - könyv formájában is közreadott. A tanulmánykötet nemcsak a témaválasztás tekintetében - a horvát barokk vizuális költészetről szóló tanulmányt éppúgy találunk benne, mint a horvát romantika, premodern és modernség alkotásaira koncentráló szöveget -, de módszertanilag is igencsak tarka képet mutat. Mégis a három Krleža-tanulmányt emelném ki, amelyek azt példázzák, hogy a magyar-horvát komparatisztika - túllépve a mü egésze szempontjából akcidentális magyar vonatkozású életrajzi és kortörténeti adatok feltárásán - lényegi észrevételekkel gazdagíthatja, sőt, paradigmaváltásra is késztetheti a krlezsológia diskurzusait.

Lukács repertoárjában olyan újszerü módszertani eszközök szerepelnek, mint a névtan, a jungi pszichoanalízis, illetve az irodalmi müvek eszmei, filozófiai gyökerének felderítése - különös tekintettel Krleža és Nietzsche kapcsolatára -, Jauss irodalomkorszakolási elmélete, vagy az intermediális megközelítés; az elmélet alkalmazása ugyanakkor nem válik öncélúvá, hanem biztos kézzel mutat rá a szövegek lényegi, struktúrateremtő jellemzőire. Nem feledkezik meg azonban a hagyományos filológia eszköztáráról sem, demonstrálva, hogy - amennyiben a kellő helyen alkalmazzuk őket - ezekkel az eljárásokkal is lenyügöző eredményekhez juthatunk. Ennek a legjobb példája talán $A$ Jesse vesszö esete egy ószláv aorisztosszal, amely a hadrovicsi filológia legszebb hagyományainak szellemében íródott. 
A szakmai és módszertani kiteljesedést $A$ passióhagyomány a horvát irodalomban [2008] című monográfiában éri el, amelyben több mint egy évtizede folytatott kutatásainak eredményét foglalja össze, többek között azokat, amelyeket a Dramatizirani kajkavski Marijin plač iz Erdelja, 1626: Dramatizált kaj-horvát Mária-siralom Erdélyböl [2000] címü monográfiájában tett közzé a Mikházán talált kaj-horvát nyelvü leletről. Monumentális összegző munkájában a horvát Mária-siralom fejlődéstörténetének, alakváltozatainak bemutatására vállalkozik, amelyröl eleddig még sehol nem született hasonló igényü szintézis. Lukács szakít a középkori horvát irodalom tanulmányozásának módszertani konzervativizmusával, és korszerü elméleti alapra építi monográfiáját. A szöveg módszertani keretét Jauss müfajelmélete adja, Hayden White és Jan Assmann elméleti eszköztárából is merít, ám a hagyományos filológia eljárásait is biztos kézzel, színvonalas módon alkalmazza. A témával kapcsolatos legújabb horvát kutatásokat is alaposan ismeri, így nemcsak a müfaj kontextusáról képes pontos képet adni, de a horvát irodalomtörténetben is precízen képes elhelyezni a passióhagyomány újonnan feltárt irányzatait. A végeredmény egy hiánypótló monográfia, amely a vállalt feladatát magas színvonalon valósítja meg, ráadásul nemzetközi összehasonlításban is megállja a helyét.

Végül, a megújuló magyar kroatisztika magának Fried Istvánnak (1934-), a közép-kelet európai régió jeles komparatistájának is igen sokat köszönhet. A cseh, a szlovák, a lengyel, a román és a délszláv irodalmakban egyaránt jártas, hihetetlenül széles látókörü tudós a régióban zajló „,irodalomtörténéseket” a legkülönbözőbb perspektívákból szemléli; tanulmányai rendszerint olyan hosszabb ideig tartó, átfogó irodalomtörténeti ill. kulturális folyamatokat tekintenek át, mint a nemzeti identitás kialakulása vagy a nyelvújítás folyamata, amelynek során az irodalmi jelenségeken túl a politika, a kultúrtörténet az eszmetörténet és a történelem releváns folyamatait sem mulasztja el számításba venni. Máskor nagy formátumú, nagy hatású magyar szerzőket helyez közép-európai kontextusba (Ady Endre és a szomszédos népek irodalma [1986]; József Attila közép-európai helye [1986]), alaposan feltárva az irodalmi müvek forrásvidékét, az egyes alkotások tipológiai párhuzamait, valamint a szerző más alkotókra tett hatását. Ezekből a körképekből természetesen a horvát irodalom perspektívája sem hiányozhat.

Újabb tanulmányaiban sorra jelennek meg a különféle posztmodern elméletek, elsősorban a kultúrkritika, az új historizmus, és helyenként a recepcióesztétika szemlélete, amelyeket a gyakorlatban is nagyszerü eredményekkel alkalmaz, anélkül, hogy a vonalasság vagy az öncélúság hibájába esne. Az Egy irodalmi régió ábrándja és kutatása [2010] címü tanulmánykötetben összegyüjtött cikkek célja már a saját és a Másik kultúráját létrehozó-megjelenítő diskurzusok jellegének, megnyilvánulási módjainak körvonalazása, e diskurzusok ütköztetése, illetve egymásba szövődésük felderítése. A cikkek visszatérő témája mégis a diskurzusok születésének helye, az Osztrák-Magyar Monarchia, amelyet Fried egy nyitott, a kultúrák találkozására és produktív interakcióira lehetőséget adó közegként értelmez újra. Rugalmasságának köszönhetően a hagyományosabb - például a müvek valóságreferenciájára vagy a 
szerzők életrajzára kérdező - megközelítések eredményeit is produktívan képes beépíteni a kultúrák párbeszédét boncolgató tanulmányokba.

Ami a kroatisztika konkrét problémáit illeti, Fried érdeklődésének középpontjában Miroslav Krleža áll (ld. „Ein Kroate aus Altösterreich”; Ambivalencia és regénytörténet), mivel életmüve a Monarchia plurális diskurzusainak kereszteződési pontjaiban formálódott, és a birodalom örökségét, ambivalens érzései ellenére, egészen haláláig továbbvitte. Fried tanulmányai, újszerü elméleti hátterüknek és egyedülállóan széles szellemi horizontjuknak köszönhetően, radikálisan átírják a korábbi Krleža-képünket, feltárva, hogy Krleža Monarchia-kritikája a maga nemében paradox. Jóllehet Krleža a Monarchia centrális, többkultúrájú diskurzusait kiüresedett, gyökértelenné vált, inautentikus beszédmódokként ábrázolja, a terjedelmes életmü máshol mégsem születhetett volna meg, hiszen pretextusa éppen a szecesszió, a szimbolizmus, a kibontakozó avantgárd osztrák-magyar-cseh együttese (ld. Fried 1993: 63).

Fried emellett a kroatisztika kérdéseit magasabb perspektívából is áttekinti; elsősorban a horvát nemzeti identitás folyamatának kialakulása, és a horvát nemzet önmagához, valamint más nemzetekhez való viszonyulása izgatja, olyan kérdéseket véve szemügyre, mint horvát irodalmi nyelv megválasztásának okai és implikációi (Nyelvújítás, nyelvválasztás - úttévesztés?), a horvát regényekben megjelenő magyarságkép (A saját meg az idegen), valamint, érintőlegesen, a horvátok 1848-ban játszott szerepe (Népek hajnalcsillaga (?)), és Széchenyi politikájának horvát recepciója (Széchenyi István és a nemzetiségi kérdés).

\section{2 Új témák, új kihívások}

Medve A. Zoltán (1961-) Kontextusok és annotációk: Adalékok az újabb horvát próza történeti-komparatív vizsgálatához [2009] címü tanulmánykötetének célkitűzése éppen a horvát próza legújabb fejleményeinek közelítése a magyar szakemberek befogadói horizontjához. A kötet fó érdeme, hogy olyan témákat emel be a magyar kroatisztikai diskurzusba, mint a Quorum címú folyóirat és köre, a horvát női próza (különös tekintettel Dubravka Ugrešić vagy Vedrana Rudan munkásságára), Nedjeljko Fabrio, Miljenko Jergović vagy éppen a FAK.

Az egyes szerzőkre-életmüvekre koncentráló szövegek mellett a kötetben kapcsolattörténeti áttekintés, valamint az irodalmi kánon és az összehasonlító irodalomtudomány jelentőségére kérdező, elméleti igényü összegzések is olvashatók. Medve nemcsak a közelmúlt horvát irodalmának kulcsszerzőit jelöli ki - a magyar irodalom jelenségeivel párhuzamba állítva -, hanem a horvát irodalom legújabb alkotásainak befogadásához is igyekszik elméleti és irodalomtörténeti kontextust biztosítani. Jóllehet a kötet azzal a megállapítással zárul, hogy a kortárs horvát és magyar próza viszonylatában csak a két kultúrára jellemző, szerkezetileg azonos tendenciák nem mutathatók ki, az érintkezési pontok többségénél pedig ,a hasonlóságon belüli eltérések” (Medve 2009: 8-9) dominálnak, maguk az összevetések igencsak tanulságosak. 
A kortárs magyar irodalom világa felől érkező szerző nemcsak témaválasztásában, de módszertani szempontból is radikálisan új hangot jelent a magyarországi kroatisztikában. Medve nagy jártassággal mozog a kortárs irodalomelmélet irányzataiban, komparatív tanulmányaiban pedig sokféle irodalomelméleti iskola fogalmait, eszközeit, sőt, a vezető horvát irodalomelméleti szakemberek gondolatait is fellelhetjük. Ebben az erényben rejlik azonban a szövegek fö hiányossága is; az elméleti referenciáknak gyakorta nincs önmagukon túlmutató célja, nem segítik elő a téma elmélyültebb, produktívabb feldolgozását, hanem megmaradnak egy felszíni-illusztratív szinten, fölöslegesen osztva meg az olvasó figyelmét, és nehezítve meg a - máskülönben szellemes érveléseket tartalmazó - szöveg befogadását.

\section{A periféria lehetőségei}

A nagy diskurzusok határterületein kialakuló beszédmódok lehetőségeit az elmúlt évtizedben a magyar kroatisztika is felismerte; két átfogó igényű munka is napvilágot látott, amelyek célja éppen a magyar és a délszláv kultúrák érintkezési pontjaiban létrejött irodalmi szövegek értékének, sajátosságainak bemutatása. Blazsetin István (1963-) 1998-ban tette közzé Književnost Hrvata u Mađarskoj od 1918. do danas (A magyarországi horvátok irodalma 1918-tól napjainkig) címü kötetet, amelynek célja a magyarországi horvát irodalom 80 évének szakszerủ áttekintése. Blazsetin, aki impozáns magyar és horvát szakirodalmi apparátussal operál, mind az irodalmon kívüli, mind az irodalmon belüli tényezőket tekintetbe veszi; kitér továbbá a szövegeket recipiáló közönség sajátosságaira, valamint a nemzetiségi folyóiratok és kritika fejlődését és a nemzetiségi irodalommal kapcsolatos polémiákat is bemutatja. Az egyes költők ismertető fejezetekben Blazsetin elsősorban a versek tematikai jellemzőit hangsúlyozza; a prozódia, ritmika, a költemény képi világa stb. kérdéseire csupán érintőlegesen tér ki, a korszerü irodalomelméleti irányzatok perspektíváinak bevonására, a szöveg- és kultúraközi kapcsolatok problematizálására pedig egyáltalán nem kerül sor.

Egy kisebbségi irodalomtörténet szerzője kivételezett helyzetben van, hiszen nemcsak a kisebbség irodalmára, hanem az anyaország és a befogadó irodalom történetére is rálát, amely az egyes országok irodalomtörténeteinek, kulturális folyamatainak egybelátását, a köztük kialakuló kulturális interakciók feltárását is lehetővé tenné. Jóllehet Blazsetin deklarált célja, hogy a horvát nemzetiségi szerzőket a magyar irodalmi áramlatok és az anyaországi horvát irodalom kontextusában is elhelyezze, csupán az irodalmak fejlődésének összevetésére - és a horvát nemzetiségi irodalom lemaradásának konstatálására - kerül sor, az irodalmak különféle áramlataihoz füződő, illetve a konkrét szövegek közötti kapcsolatokról alig-alig esik szó. A kötet szerzőportrékat tartalmazó része az irányzatok egymásra hatásának és a szövegközi kapcsolatoknak a részletesebb elemzését is lehetővé tette volna, ugyanakkor ez is elmarad, annak ellenére, hogy a magyarországi horvát irodalomban több olyan szerző is akadt - például 
Josip Gujaš Džuretin -, aki a korabeli horvát és magyar irodalom fejlődését egyaránt figyelemmel kísérte.

A kisebbségi irodalom kérdésének radikálisan eltérö megközelítését láthatjuk A szomszédság kapui [2010] címü tanulmánykötetben, amelyben Virág Zoltán (1966-) a vajdasági magyar irodalom jelentős képviselőit bemutató portréit adja közre. A kötet legfontosabb része az Új Symposion folyóirat történetét, jelentőségét, vezéregyéniségeit bemutató tanulmány, amelyet a folyóirat köré gyült alkotók portréja (Tolnai Ottó, Böndör Pál, Maurits Ferenc, Juhász Erzsébet, Balázs Attila, Sziveri János, Jódal Kálmán) követ, ugyanakkor több tanulmányt olvashatunk a vajdasági magyar irodalom alapító egyénisége, Szenteleky Kornél pályájáról. Némileg kilóg a sorból az Érintkezések és áthallások címú tanulmány, amely a 20. század második felének magyarországi horvát irodalmáról ad áttekintést - szemlélete, vizsgálati szempontjai okán azonban mégis szervesen kapcsolódik a kötetben található többi tanulmányhoz.

A tanulmányokat olvasva arra a következtetésre juthatunk, hogy Virágot voltaképpen a kisebbségi lét ontológiája érdekli. Valamennyi tanulmányban hangsúlyozza, hogy a perifériális lét lényege a többféle kultúrának való kitettség, amely nem csupán az egyéni identitás megalkotásának szempontjából döntő, hanem egyszersmind az alkotói lét legfontosabb lehetősége. Az egyén döntése, hogy helyzetét ,az idegentapasztalat kárvallottjaként” éli-e meg, vagy pedig felvállalja a saját és az idegen szembeállításának-ütköztetésének misszióját, amelynek komoly tétje van, hiszen az idegen megtapasztalása megkérdőjelezheti, sőt, akár szét is zúzhatja a saját kultúráról, irodalomról, nyelvről, egyéniségről való gondolkodás stabilizált módozatait. Ez a szembesülés ugyanakkor messzemenően produktív lehet, hiszen olyan felismerésekhez, paradigmaváltásokhoz vezethet, amelyekből mind az anyaország, mind a befogadó ország kultúrája profitálhat - ahogyan ez a symposionisták esetében meg is történt. Akármelyik alkotóról szól is, Virág számára az elsődleges kérdés az, miképpen aknázza ki privilegizált helyzetét, és hogyan képes funkcionálni a befogadó ország és az anyaország kulturális mátrixában; ezért nemcsak a magyar, de a horvát, a szerb és a szlovén irodalom főbb áramlataihoz, diskurzusaihoz, sőt, az egyes délszláv szerzők beszédmódjához, metaforikájához és motívumaihoz füződő szálakat is igyekszik feltérképezni.

Virág esszéi rendkívül esszenciálisak, a kulturális allúziók számbavételén túl az ismertetett életmünek szinte valamennyi strukturális szintjére kitérnek, a felvetett témáktól és az eszmei háttértől kezdve a szövegek makroszerkezetén át egészen a prozódiáig, a szövegek akusztikai megformáltságáig, vagy éppen azok képi világáig. Mindennek előfeltétele a tanulmányok sajátságos, már-már a líraiságot súrolóan esszéisztikus nyelvezete, amely egyszerre teszi lehetővé a precíz és szakszerü állítások megfogalmazását, a befogadói élmény plasztikus visszaadását, illetve a szerteágazó irodalomelméleti eszköztár integrálását. Jóllehet az elméleti utalások valamennyi tanulmányban permanensen jelen vannak, az elmélet alkalmazása nem válik vonalassá vagy öncélúvá, hanem szervesen simul bele a szövegbe, hozzájárulva az életművek mélyebb megért(et)éséhez. 


\section{A kroatológia Magyarországon}

A magyar kroatisztika körképét egy olyan kézikönyv bemutatásával zárjuk, amely azzal a céllal íródott, hogy tömör, ám teljes értékü áttekintést nyújtson az érdeklődőknek a horvátság kultúrájáról. Bár Heka László (1959-) könyve, a Horvátország kulturális és müvészettörténete, a Bevezetés a kroatisztikába alcímet viseli, célkitűzései mégis a közelmúltban megjelent új diszciplínához, a kroatológiához állnak közelebb. A Radoslav Katičić által kezdeményezett megközelítés a horvát filológia hagyományos területei mellett számos egyéb diszciplína, például a történelemtudomány, a zene-, a filozófia- és a tudománytörténet eredményeit is figyelembe veszi, s egy nagyobb kulturális egység - egymással összefüggő, sőt, állandó interakcióban lévő - különböző aspektusaiként tekint rájuk.

Maga a könyv - a cím által sugalltakkal ellentétben - négy nagyobb egységből áll, amelyek közül az első Horvátország földrajzát, a második Horvátország történelmét ismerteti, a harmadik ugyanazt a címet viseli, amit a könyv fedelén is olvashatunk, a negyedik egység célja pedig a „horvát nyelv és irodalom” bemutatása. Heka rálátása az ismertetett területekre fölöttébb korlátozott, a feldolgozott területek szakkifejezéseit, módszertanát nem ismeri, ráadásul a témákat igen kevés forrásra támaszkodva, a mértékadó szakirodalom csaknem teljes mellőzésével mutatja be. Egyes fejezetekben egyenesen az az olvasó érzése, hogy a szerző saját - meglehetősen felületes - ismereteit próbálja szavakba önteni. Az eredmény sejthető: a kötetben mind formai, mind tartalmi téren sok a pontatlanság, az apró tévedésektől kezdve a durva hibákig.

Súlyos probléma továbbá, hogy a könyv tematikai egységei nem állnak össze egységes egésszé: a feldolgozásuk kimerül a tényanyag - priorizálás nélküli felhalmozásában. A szerző meg sem próbálkozik azzal, hogy a leírt adatokból következtetéseket vonjon le a terület fejlődésére vonatkozóan, netán felvillantsa a bemutatott tematikai egységek összefüggéseit, egymásra hatásuk mikéntjét. A könyv fejezetei átgondolatlanul összerótt adathalmazoknak hatnak, amelyekben a szerepeltetett információk nem épülnek egymásra, nem forrnak össze szerves egésszé; ráadásul, a fejezetek megmaradnak elszigetelt „,világoknak”, ahelyett, hogy egyetlen, átfogó képet nyújtanának Horvátország kultúrájáról.

Tovább tetézi mindezt az általános hanyagság, amely a szöveg valamennyi szintjén megjelenik - a szükebb értelemben vett tartalomtól kezdve egészen a helyesírásig és a tördelésig, a stílustalan, magyartalan, sokszor értelmetlenül zavaros mondatokig, olyan hibákkal, amelyek egy egyszerü, hétköznapi kiadvány esetében is megengedhetetlenek, de egy minisztériumi támogatásban részesült egyetemi tankönyvnél már-már az abszurditás határát súrolják.

Nagy szükség lenne már egy korszerü szemléletü kiadványra, amely rövid, ám teljes körü áttekintést adna szomszédunk kultúrájáról, történelméről és irodalmáról. Heka László könyve sajnos erre nem alkalmas - a koncepció kiforratlansága, az összegyűjtött tényanyag rendszerezésének, továbbgondolásának hiánya miatt a könyvből éppen az a belső kohézió hiányzik, ami a kroatológiai megközelítés lényegét adná. Remélhetőleg rövidesen megszületik 
az a kroatológiai kézikönyv, amely hasonlóan tömör, ugyanakkor szakszerü és olvasmányos módon mutatja be Horvátország kultúráját.

\section{5 Összegzés}

Az 1990-es években bekövetkezett politikai változások okán a magyarországi irodalmi kroatisztikának számos új kihívással kellett szembenéznie, mint az „,irodalomelméleti fordulat” konzekvenciáinak levonása, a posztmodern horvát irodalom magyarországi közvetítésének kérdése, valamint a magyar és a horvát kisebbségi irodalmak valódi jelentőségének megmutatása. Jóllehet a kihívások felismerése és a rájuk adott reakció nem volt egységes, a kroatisztikai diskurzusokban új korszakok (az illírizmustól egészen napjaink irodalmáig) és új témák (például a horvát nemzetkép és a többkultúrájú identitás kérdése) jelentek meg, és kétségtelenül színre lépett néhány olyan szakember, akik nem mindennapi problémaérzékenységüknek, kroatisztikai és irodalomelméleti felkészültségüknek köszönhetően új, korszerü, nemzetközi összehasonlításban is magas színvonalat képviselő irányokat jelölhettek ki a magyar kroatisztika diskurzusai számára.

\section{FELHASZNÁLT IRODALOM}

Stjepan BLAŽETIN, 1998: Književnost Hrvata u Mađarskoj od 1918. do danas. Osijek: Matica Hrvatska.

István FRIED, 1986a: Ady Endre és a szomszédos népek irodalma. Kelet- és Közép-Európa között. Budapest: Gondolat. 161-170.

--, 1986b: József Attila közép-európai helye. Kelet- és Közép-Európa között. Budapest: Gondolat. 212-222.

--, 1993: „Ein Kroate aus Altösterreich”. Tiszatáj 47/7, 53-66.

- -, 1997: Utak a komparatisztikában. Budapest: JATE BTK Összehasonlító Irodalomtudományi Tanszék.

- -, 2010: Egy irodalmi régió ábrándja és kutatása. Budapest: Lucidus.

László HEKA, 2004: Horvátország kulturális és müvészettörténete. Szeged: Bába kiadó. István LÖKÖS, 1984: Magyar és délszláv irodalmi tanulmányok. Budapest: Szépirodalmi Könyvkiadó.

- -, 1996: A horvát irodalom története. Budapest: Nemzeti Tankönyvkiadó.

--, 1997a: Déli szláv-magyar szellemi kapcsolatok. Miskolc: Felsőmagyarország Kiadó. - -, 1997b: Zrinyi eposzának horvát epikai elözményei. Debrecen: Kossuth Egyetemi Kiadó. 
--, 1997c: A Kaptoltól a Ludovikáig. Budapest: Nemzeti Tankönyvkiadó.

--, 2002: Nemzettudat, nyelv és irodalom. Budapest: Lucidus.

- -, 2004: Nemzettudat és regény. Debrecen: Kossuth Egyetemi Kiadó.

--, 2007: Horvát-magyar és szerb-magyar irodalmi interferenciák. Budapest: Lucidus.

István LUKÁCS, 2000: Dramatizirani kajkavski Marijin plač iz Erdelja, 1626 - Dramatizált kaj-horvát Mária-siralom Erdélyből. Budimpešta: Slovenika i Hrvatska samouprava Budimpešte.

- -, 2004: Térközök. Budapest: ELTE BTK Szláv Filológiai Tanszék.

- -, 2008: A passióhagyomány a horvát irodalomban. Budapest: ELTE BTK Szláv Filológiai Tanszék.

Zoltán A. MEDVE, 2009: Kontextusok és annotációk. Budapest: Kijárat.

Zoltán VIRÁG, 2011: A szomszédság kapui. Zenta: zEtna-Basiliscus.

\section{MADŽARSKA LITERARNA KROATISTIKA V BLIŽNJI PRETEKLOSTI}

V prispevku je podan pregled razvoja madžarske literarne kroatistike $\mathrm{v}$ času po spremembi političnega sistema. V 90-ih letih 20. stoletja se je raziskovanje hrvaške literature namreč moralo soočiti s številnimi novimi izzivi, npr. s posledicami literarnoteoretičnega preobrata, $\mathrm{z}$ vprašanjem posredovanja postmodernistične hrvaške - predvsem vojne - književnosti 90-ih let na Madžarskem ter s ponovnim določanjem in ovrednotenjem madžarske in hrvaške manjšinske književnosti. Namen pričujočega prispevka je predstaviti, kako so ta vprašanja rešile najpomembnejše osebnosti madžarske kroatistike in kako so razširile horizont madžarske literarne kroatistike. Kot odgovor na ta vprašanja so $\mathrm{v}$ prispevku skicirani portreti najpomembnejših osebnosti madžarske kroatistike (Stipan Blažetin, István Fried, László Heka, István Lőkös, Stjepan Lukač, Zoltán A. Medve, Zoltán Virág), kritično pa so predstavljena tudi njihova najpomembnejša dela, cilji in metodološka sredstva. 